\title{
Cerulenin Inhibits Production of Extracellular Proteins but not Membrane Proteins in Bacillus amyloliquefaciens
}

\author{
By JAMES C. PATON, BRIAN K. MAY* AND WILLIAM H. ELLIOTT \\ Department of Biochemistry, University of Adelaide, Adelaide, \\ South Australia 5001, Australia
}

(Received 29 August 1979; revised 29 October 1979)

\begin{abstract}
Cerulenin inhibited the secretion of extracellular proteins by washed cell suspensions of Bacillus amyloliquefaciens. $\alpha$-Amylase and protease secretion were inhibited by $80 \%$ and $75 \%$, respectively, over $3 \mathrm{~h}$. Cerulenin at $100 \mu \mathrm{g} \mathrm{m} \mathrm{m}^{-1}$ inhibited incorporation of $\left[1,2-{ }^{14} \mathrm{C}\right]-$ acetate into intracellular lipid by about $75 \%$ without affecting cell growth, total protein synthesis or membrane protein synthesis. The inhibitory effect of cerulenin on $\alpha$-amylase and protease secretion could be partially reversed if cell suspensions were supplemented with either fatty acids prepared from the lipids extracted from $B$. amyloliquefaciens or various individual pure fatty acids. Cerulenin significantly altered the ratio of lipid to protein in isolated membranes. However, this alteration was not affected by adding fatty acids which restored enzyme secretion. These results suggest that cerulenin may affect the availability of lipid directly concerned with the secretion process. The differential effect of cerulenin on the production of extracellular proteins and membrane proteins also suggests that the synthesis of these two classes of proteins occurs via mechanisms that differ.
\end{abstract}

\section{INTRODUCTION}

Recent observations suggest a possible link between lipid synthesis and secretion of proteins in bacteria. Cerulenin, a specific inhibitor of fatty acid synthetase (Omura, 1976), inhibits the formation of levansucrase in Bacillus subtilis (Caulfield et al., 1976), penicillinase in Bacillus licheniformis (Fishman et al., 1978) and enterotoxins in Staphylococcus aureus (Altenbern, 1977). In addition, the peripheral membrane protein of $E$. coli, aminopeptidase $\mathrm{N}$, is dependent upon concurrent lipid synthesis for either its transfer across, or proper insertion into, the cytoplasmic membrane (Lazdunski et al., 1979).

We have been studying the mechanism of secretion of the extracellular enzymes $\alpha$-amylase and protease by Bacillus amyloliquefaciens (O'Connor et al., 1978; Sanders \& May, 1975). In the present work, we have examined the effect of cerulenin on the secretion of these enzymes and of all extracellular proteins by this organism. In addition, the effect of cerulenin on the production of integral membrane proteins was studied.

\section{METHODS}

Growth of organism. A mutant strain of Bacillus amyloliquefaciens that does not secrete 'surfactin' (Sanders \& May, 1975) was grown from a spore inoculum in a medium described previously (Both et al., 1972). Flasks were incubated at $30^{\circ} \mathrm{C}$ with shaking. Cells were harvested after $18 \mathrm{~h}$ when they had reached the late-exponential phase of growth $\left(A_{600}=3 \cdot 6 ; 3 \mathrm{mg}\right.$ dry wt ml $\left.\mathrm{m}^{-1}\right)$.

Experimental washed cell suspensions. Harvested cells were washed and suspended in washed cell suspension medium (WCSM) i.e. growth medium without $\mathrm{FeCl}_{3}$ and yeast extract. Cell suspensions were incubated at $30{ }^{\circ} \mathrm{C}$ with shaking.

Cerulenin (Makor Chemicals, Jerusalem, Israel) was dissolved in ethanol to give $20 \mathrm{mg} \mathrm{ml}^{-1}$ and added to 
cell suspensions to give $100 \mu \mathrm{g} \mathrm{ml}^{-1}$. An equal volume of ethanol (giving $0.5 \%, \mathrm{v} / \mathrm{v}$ ) was added to control cell suspensions.

Assays for enzyme activity. $\alpha$-Amylase (EC 3.2.1.1) was assayed using an insoluble cross-linked blue starch polymer substrate, purchased as Phadebas tablets from Pharmacia Diagnostics. One tablet was suspended in $7 \mathrm{ml}$ of buffer, $\mathrm{pH} 6 \cdot 2$, containing $10 \mathrm{~mm}$-potassium phosphate, $25 \mathrm{~mm}-\mathrm{NaCl}$ and $0.4 \mathrm{~mm}$ $\mathrm{CaCl}_{2}$, and $1.4 \mathrm{ml}$ amounts were dispensed into tubes. The reaction was started by adding enzyme $(100 \mu \mathrm{l})$ and the tubes were incubated at $37{ }^{\circ} \mathrm{C}$. The reaction was stopped by adding $0.2 \mathrm{ml} 0.5 \mathrm{M}-\mathrm{NaOH}$, and, after centrifuging, the $A_{620}$ of the supernatant was determined. One unit of $\alpha$-amylase activity was arbitrarily defined as that amount of enzyme that produced a change in $A_{620}$ of 4.0 in 30 min at $37^{\circ} \mathrm{C}$.

Protease (EC 3.4.21 .14) was assayed by the Remazol brilliant blue-hide powder method of Rinderknecht et al. (1968).

Measurement of total fatty acid synthesis. Washed cells in WCSM were incubated with $\left[1,2-{ }^{14} \mathrm{C}\right]$ acetate [2.5 $\mu \mathrm{Ci} \mathrm{ml}^{-1} ; 96.8 \mathrm{mCi} \mathrm{mmol}^{-1}\left(3.58 \mathrm{GBq} \mathrm{mmol}^{-1}\right)$; Schwarz-Mann, Orangeburg, N.Y., U.S.A.]; the WCSM was supplemented with $10 \mathrm{~mm}$-sodium acetate as carrier. Suspensions were incubated at $30^{\circ} \mathrm{C}$ with shaking and at intervals $0.25 \mathrm{ml}$ samples were withdrawn and added to $4 \mathrm{ml}$ of ice-cold 1 M-sodium acetate. The cells were collected by centrifuging, taken up in $1 \mathrm{ml} 1 \mathrm{M}$-sodium acetate and the lipids were then extracted by a method described previously (Paton et al., 1978a). The total radioactive lipid extract of each sample was counted by liquid scintillation.

Separation of labelled secreted proteins. Cells in WCSM were incubated with ${ }^{35}$ S $]$ methionine $\left[10 \mu \mathrm{Ci} \mathrm{ml}^{-1}\right.$; $770 \mathrm{Ci} \mathrm{mmol}^{-1}\left(28.5 \mathrm{TBq} \mathrm{mmol}^{-1}\right)$; The Radiochemical Centre, Amersham] and then removed by centrifugation. Proteins in the supernatant were precipitated by adding trichloroacetic acid to a final concentration of $10 \%(\mathrm{w} / \mathrm{v})$. The pellets were washed three times with ethanol and twice with diethyl ether, and then suspended in $2 \%$ sodium dodecyl sulphate (SDS) containing 5\%(v/v) 2-mercaptoethanol and boiled for $5 \mathrm{~min}$. The proteins were then separated by SDS-gel electrophoresis using $12.5 \%(\mathrm{w} / \mathrm{v})$ polyacrylamide gels according to the method of Laemmli (1970) and fluorographed by the method of Bonner \& Laskey (1974).

Measurement of extracellular and total cellular protein synthesis. Cells in WCSM were incubated with L- $\left[4,5-{ }^{3} \mathrm{H}\right]$ leucine $\left[2 \mu \mathrm{Ci} \mathrm{ml}^{-1} ; 105 \mathrm{Ci} \mathrm{mmol}^{-1}\left(3.88 \mathrm{TBq} \mathrm{mmol}^{-1}\right)\right.$; The Radiochemical Centre, Amersham]. To measure total protein synthesis, $0.1 \mathrm{ml}$ samples were withdrawn and added to $3 \mathrm{ml} 10 \%(\mathrm{w} / \mathrm{v})$ trichloroacetic acid containing $1 \%(\mathrm{w} / \mathrm{v})$ Casamino acids. To measure extracellular protein synthesis, $0 \cdot 2 \mathrm{ml}$ samples were withdrawn, centrifuged $(4000 \mathrm{~g}, 5 \mathrm{~min})$ and $0.1 \mathrm{ml}$ of the supernatant was added to $3 \mathrm{ml} 10 \%(\mathrm{w} / \mathrm{v})$ trichloroacetic acid containing $1 \%(\mathrm{w} / \mathrm{v})$ Casamino acids; $20 \mu \mathrm{l} 5 \%(\mathrm{w} / \mathrm{v})$ bovine serum albumin was added as a carrier. The various samples were then processed as previously described (Both et al., 1972) and counted by liquid scintillation.

Preparation of fatty acids. Cell lipids, isolated as described above, were saponified by refluxing for $3 \mathrm{~h}$ in $1 \mathrm{M}-\mathrm{NaOH}$ in $50 \%$ (v/v) methanol. Non-saponifiable material was removed by extracting three times with $n$-hexane. The aqueous phase was acidified with $10 \mathrm{M}-\mathrm{H}_{2} \mathrm{SO}_{4}$ and fatty acids were extracted with diethyl ether. After neutralizing with $\mathrm{NH}_{4} \mathrm{OH}$ and removing solvent under $\mathrm{N}_{2}$, the fatty acids were taken up in $50 \mathrm{~mm}$-Tris/ $\mathrm{HCl}, \mathrm{pH} 7 \cdot 3$, to give $10 \mathrm{mg} \mathrm{ml}^{-1}$.

Radioactively labelled $B$. amyloliquefaciens fatty acids were prepared by the above method from cells that had been grown from spore inoculum in the presence of $\left[1,2-{ }^{14} \mathrm{C}\right]$ acetate $\left(5 \mu \mathrm{Ci} \mathrm{ml}{ }^{-1}\right)$.

Purified branched-chain fatty acids (anteiso acids of 15 and 17 carbon atoms and the iso acid with 16 carbon atoms) were purchased as methyl esters from Applied Science Laboratories, Pa., U.S.A. They were hydrolysed for $2 \mathrm{~h}$ at $80^{\circ} \mathrm{C}$ in $1 \mathrm{M}-\mathrm{NaOH}$ in $50 \%$ (v/v) methanol, and after acidifying with $\mathrm{H}_{2} \mathrm{SO}_{4}$ the fatty acids were extracted with diethyl ether. These fatty acids, and also palmitic acid, were neutralized with $\mathrm{NH}_{4} \mathrm{OH}$,

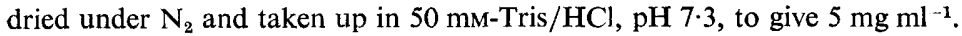

Preparation and analysis of membranes. Washed cytoplasmic membranes were prepared from B. amyloliquefaciens by the method of Konings et al. (1973).

Protein content was determined by the method of Lowry. To determine their lipid content, membrane samples were extracted as described above. The lipid extracts were placed in tared tubes, dried under vacuum and weighed.

Analysis of membrane proteins was carried out on membranes prepared from cells that had been incubated for $3 \mathrm{~h}$ in the presence of $\left[{ }^{35} \mathrm{~S}\right]$ methionine $\left(1 \mu \mathrm{Ci} \mathrm{ml}^{-1}\right)$. Washed, labelled membranes were precipitated with $10 \%(\mathrm{w} / \mathrm{v})$ trichloroacetic acid and analysed by SDS-polyacrylamide gel electrophoresis and fluorography, as described above.

Respiratory studies. Rates of $\mathrm{O}_{2}$ uptake were measured using an $\mathrm{O}_{2}$ electrode (Rank Bros, Cambridge) connected to a millivolt recorder. The electrode was calibrated with air-saturated water at $30^{\circ} \mathrm{C}$ and the reaction was carried out in WCSM. 


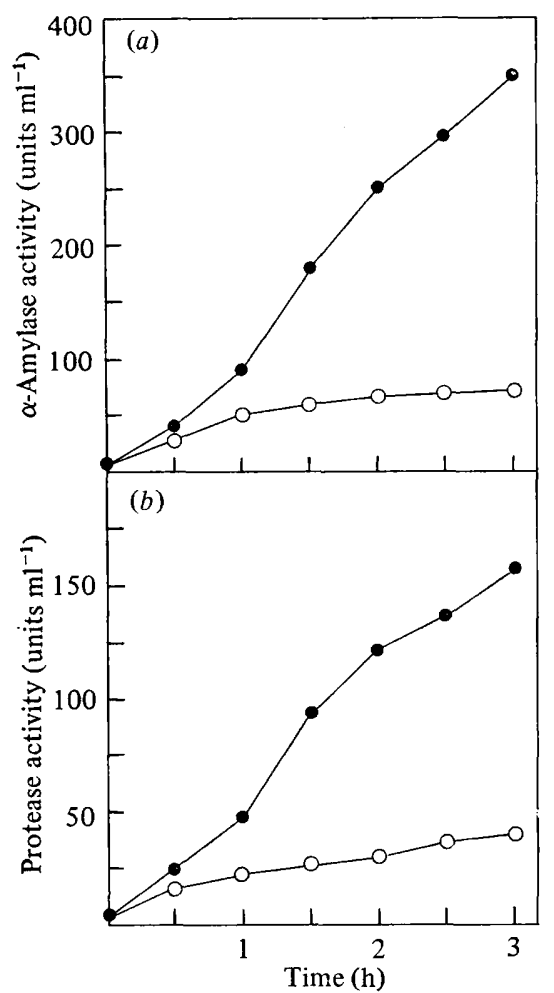

Fig. 1

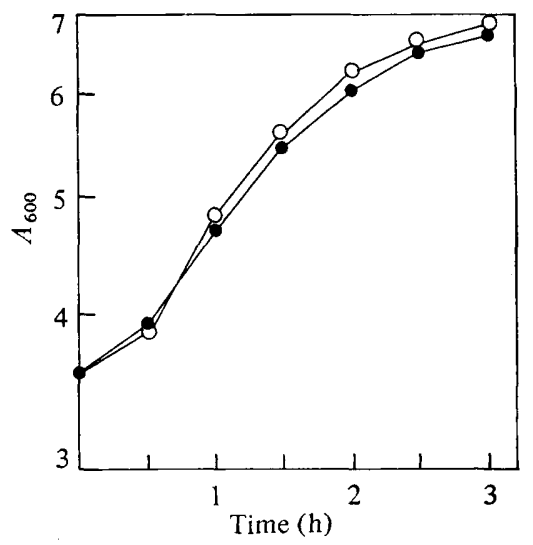

Fig. 2

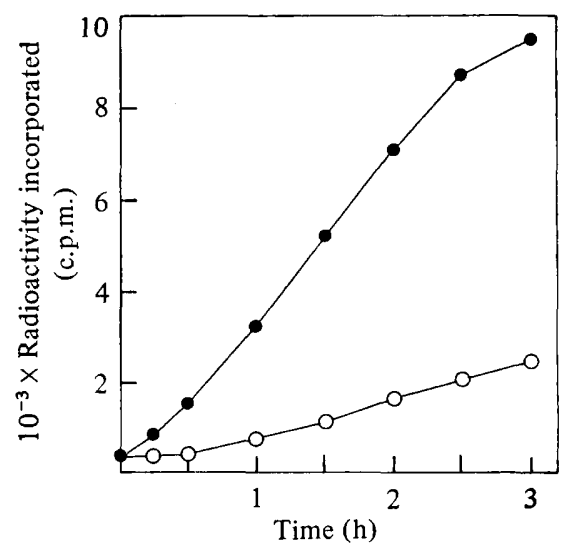

Fig. 3

Fig. 1. Effect of cerulenin on extracellular enzyme secretion by B. amyloliquefaciens. Cells were washed and resuspended in WCSM. Suspensions of cells $(2 \mathrm{ml})$ were incubated with $(\bigcirc)$ or without (O) cerulenin $\left(100 \mu \mathrm{g} \mathrm{m}^{-1}\right)$. At intervals $0.15 \mathrm{ml}$ samples were withdrawn, centrifuged $(4000 \mathrm{~g}$, $5 \mathrm{~min}$ ) and the supernatants were assayed for $\alpha$-amylase $(a)$ or protease $(b)$ activity as described in Methods.

Fig. 2. Effect of cerulenin on cell growth. Suspensions of B. amyloliquefaciens in WCSM were incubated with $(O)$ or without $(O)$ cerulenin $\left(100 \mu \mathrm{g} \mathrm{ml}^{-1}\right)$. At intervals samples were withdrawn, appropriately diluted in $0.9 \%(\mathrm{w} / \mathrm{v}) \mathrm{NaCl}$ and their $\boldsymbol{A}_{600}$ was measured.

Fig. 3. Effect of cerulenin on $\left[1,2-{ }^{14} \mathrm{C}\right]$ acetate incorporation into lipid by $B$. amyloliquefaciens. Suspensions of cells $(5 \mathrm{ml})$ were incubated with $\left[1,2-{ }^{14} \mathrm{C}\right]$ acetate $\left(2 \cdot 5 \mu \mathrm{Ci} \mathrm{ml}{ }^{-1}\right)$ in the absence $(\odot)$ or presence $(O)$ of cerulenin $\left(100 \mu \mathrm{g} \mathrm{ml}^{-1}\right)$. At intervals $0.25 \mathrm{ml}$ samples were withdrawn and the radioactivity incorporated into lipid was determined as described in Methods.

\section{RESULTS}

Inhibition of extracellular protein synthesis by cerulenin

When washed suspensions of $B$. amyloliquefaciens were incubated with cerulenin $(100 \mu \mathrm{g}$ $\mathrm{ml}^{-1}$ ), the secretion of $\alpha$-amylase (Fig. $1 \mathrm{a}$ ) and protease (Fig. $1 b$ ) was inhibited over $3 \mathrm{~h}$ by $80 \%$ and $75 \%$, respectively. Under these conditions, cell growth was unaffected (Fig. 2). The incorporation of $\left[1,2-{ }^{14} \mathrm{C}\right]$ acetate into total cell lipid was almost totally inhibited by cerulenin over the first $15 \mathrm{~min}$ but subsequently recovered to about $30 \%$ of the control rate (Fig. 3).

To check if the inhibition of enzyme secretion (Fig. 1) was due to the production of inactive 


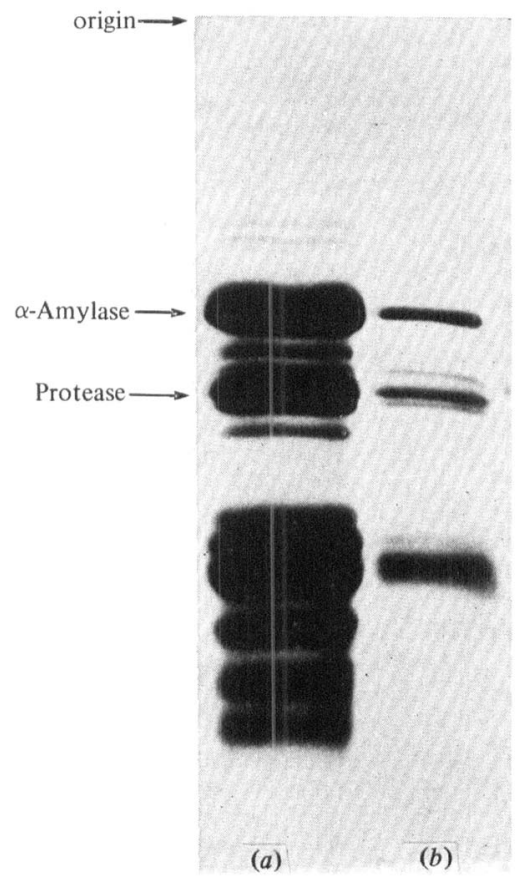

Fig. 4. Effect of cerulenin on extracellular protein secretion by B. amyloliquefaciens. Suspensions of cells were incubated for $3 \mathrm{~h}$ with $\left.{ }^{35} \mathrm{~S}\right]$ methionine $\left(10 \mu \mathrm{Ci} \mathrm{ml}^{-1}\right)$ in the absence $(a)$ or presence $(b)$ of cerulenin $\left(100 \mu \mathrm{g} \mathrm{ml}^{-1}\right)$. The suspensions were then centrifuged $(4000 \mathrm{~g}, 5 \mathrm{~min})$ and the proteins in the supernatant were separated by SDS-polyacrylamide gel electrophoresis and fluorographed as described in Methods. The mobilities of $\alpha$-amylase and protease are indicated.

enzyme molecules, cells were incubated for $3 \mathrm{~h}$ with $\left.{ }^{[35} \mathrm{S}\right]$ methionine in the presence or absence of the drug; the cells were removed by centrifuging and the proteins secreted into the medium were analysed by SDS-polyacrylamide gel electrophoresis and fluorography (see Methods). The amount of every protein secreted by the cells was greatly decreased by the presence of cerulenin (Fig. 4). The incorporation of $\left[{ }^{3} \mathrm{H}\right]$ leucine into total secreted protein, measured as trichloroacetic acid insoluble material, was inhibited by about $75 \%$ by the drug (Fig. 5a).

When the incorporation of $\left[{ }^{3} \mathrm{H}\right]$ leucine into total (intracellular plus extracellular) protein was measured in the presence and absence of cerulenin, only a slight inhibition by the drug was observed (Fig. $5 b$ ). Since extracellular protein synthesis represents approximately $5 \%$ of total cellular protein synthesis measured in this way (compare Figs $5 a$ and $5 b$ ) the small inhibition observed presumably reflects a selective inhibition of extracellular enzyme production.

\section{Reversal of cerulenin inhibition of enzyme secretion}

The observed effects of cerulenin were reversible. When cerulenin was removed from the cells by washing $1 \mathrm{~h}$ after its addition, $\left[{ }^{14} \mathrm{C}\right]$ acetate incorporation into lipid was immediately restored to the control rate (Fig. $6 a$ ). Under these conditions, $\alpha$-amylase secretion also completely recovered after a $60 \mathrm{~min}$ lag (Fig. $6 b$ ).

The inhibition of $\alpha$-amylase and protease secretion by cerulenin was significantly reversed by the addition of fatty acids obtained by hydrolysis of total cell lipids (see Methods). The principal fatty acids of this organism are the branched-chain acids of 15, 16 and 17 carbon atoms and palmitic acid (Paton et al., 1978 b). When the total cellular fatty acid mixture and the drug were added simultaneously to cell suspensions, the rate of $\alpha$-amylase secretion after $1 \mathrm{~h}$ was more than three times the rate of secretion in the presence of cerulenin alone and 


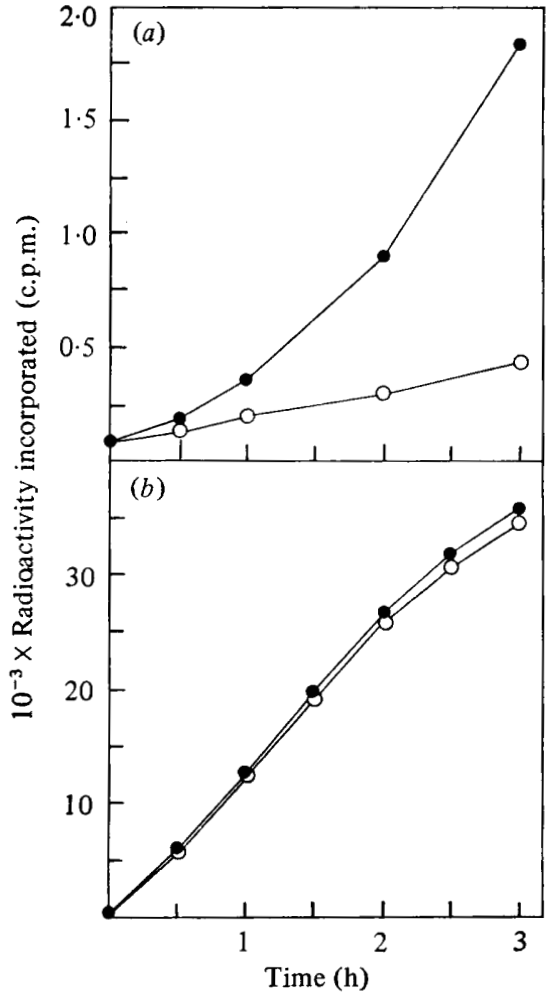

Fig. 5

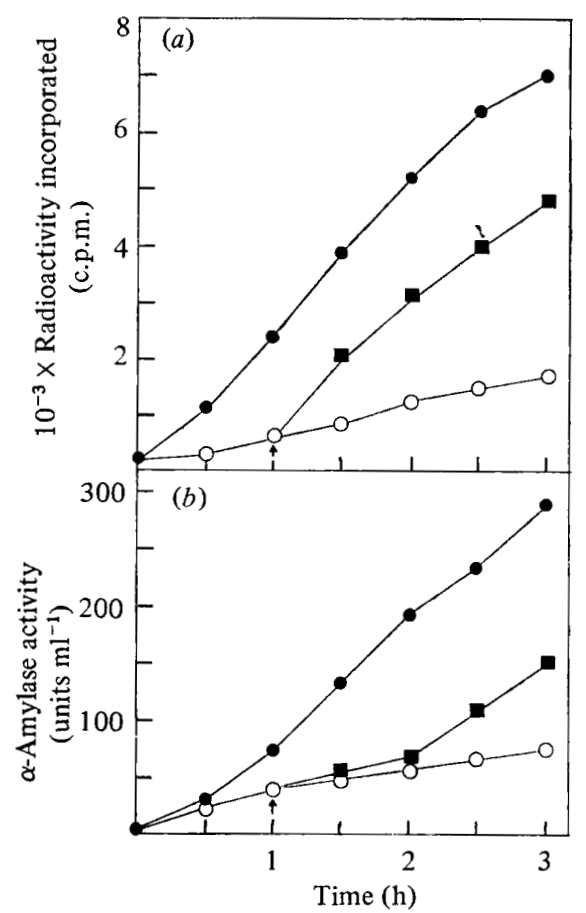

Fig. 6

Fig. 5. Effect of cerulenin on $\left[{ }^{3} \mathrm{H}\right]$ leucine incorporation into extracellular protein and total cellular protein by $B$. amyloliquefaciens. Suspensions of cells $(5 \mathrm{ml})$ were incubated with [ $\left.{ }^{3} \mathrm{H}\right]$ leucine $\left(2 \mu \mathrm{Ci} \mathrm{m}^{-1}\right)$ in the absence $(O)$ or presence $(O)$ of cerulenin $\left(100 \mu \mathrm{g} \mathrm{ml}^{-1}\right)$. At intervals samples were withdrawn and the radioactivity incorporated into extracellular protein $(a)$ and total cell protein $(b)$ was measured as described in Methods.

Fig. 6. Reversal of cerulenin inhibition of fatty acid synthesis and $\alpha$-amylase secretion by removal of the drug. Suspensions of cells were incubated with $\left.\left[1,2 \cdot{ }^{14} \mathrm{C}\right] \mathrm{acetate}(2 \cdot 5 \mu \mathrm{Ci} \mathrm{ml})^{-1}\right)$ in the absence (O) or presence $(O)$ of cerulenin $\left(100 \mu \mathrm{g} \mathrm{ml}^{-1}\right)$. After $1 \mathrm{~h}$ (arrow) a portion ( $\boldsymbol{C}$ ) was withdrawn from the cerulenin-treated cells, washed and resuspended in fresh WCSM containing $\left[1,2-{ }^{14} \mathrm{C}\right]$ acetate, but without cerulenin, and then incubation was continued. At intervals samples were withdrawn; the radioactivity incorporated into cell lipid $(a)$ was measured as described in Methods, and secretion of $\alpha$-amylase $(b)$ was measured as described in the legend to Fig. 1.

was approximately $50 \%$ of the untreated control rate (Fig. 7). Under similar conditions, the rate of protease secretion was stimulated more than twofold to $40 \%$ of the control rate (Fig. 8). Further reversal of $\alpha$-amylase and protease inhibition was not achieved by the addition of greater amounts of the fatty acid mixture.

The reversal of the cerulenin inhibition of extracellular enzyme secretion by adding exogenous fatty acids was not due to a simple relief of the inhibition of fatty acid synthesis as the poor incorporation of $\left[1,2-{ }^{14} \mathrm{C}\right]$ acetate into lipid in the presence of cerulenin was unaffected by adding the fatty acid mixture.

Individual fatty acid species added singly also partially reversed the effects of cerulenin on enzyme secretion. Anteiso- $\mathrm{C}_{15: 0}$, iso- $\mathrm{C}_{16: 0}$, anteiso- $\mathrm{C}_{17: 0}$, and $n-\mathrm{C}_{16: 0}$ added at 50, 100, 100 and $50 \mu \mathrm{g} \mathrm{ml}^{-1}$, respectively (concentrations which were optimal) increased the total amount of enzyme secreted in the presence of cerulenin up to twofold (Table 1). 


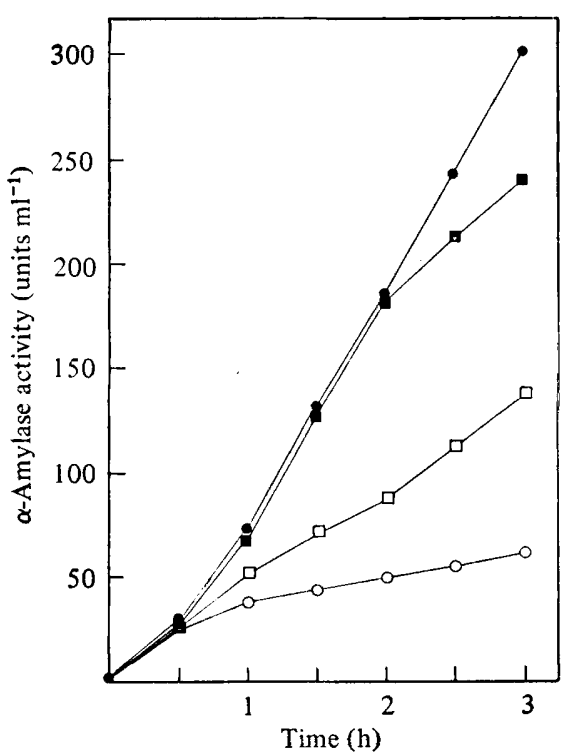

Fig. 7

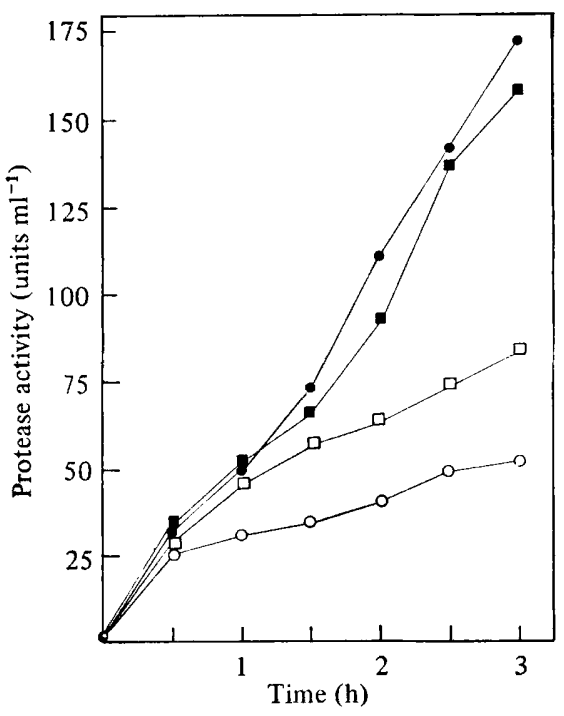

Fig. 8

Fig. 7. Reversal of cerulenin inhibition of $\alpha$-amylase secretion by fatty acids. Suspensions of cells $(2 \mathrm{ml})$ were incubated in the absence $(\boldsymbol{G}, \boldsymbol{0})$ or presence $(\square, 0)$ of cerulenin $\left(100 \mu \mathrm{g} \mathrm{ml}^{-1}\right)$ with $(\square, \square)$ or without $(\bigcirc, \bigcirc) B$. amyloliquefaciens fatty acids $\left(100 \mu \mathrm{g} \mathrm{ml}^{-1}\right)$. At intervals $0 \cdot 15 \mathrm{ml}$ samples were withdrawn, centrifuged $(4000 \mathrm{~g}, 5 \mathrm{~min})$ and the supernatants were assayed for $\alpha$-amylase as described in Methods.

Fig. 8. Reversal of cerulenin inhibition of protease secretion by fatty acids. Suspensions of cells $(2 \mathrm{ml})$ were incubated in the absence $(\boldsymbol{\square}, \boldsymbol{O})$ or presence $(\square, O)$ of cerulenin $\left(100 \mu \mathrm{g} \mathrm{ml}^{-1}\right)$ with $(\square, \square)$ or without $(\bigcirc, \bigcirc) B$. amyloliquefaciens fatty acids $\left(100 \mu \mathrm{g} \mathrm{ml}^{-1}\right)$. At intervals $0 \cdot 15 \mathrm{ml}$ samples were withdrawn, centrifuged $(4000 \mathrm{~g}, 5 \mathrm{~min})$ and the supernatants were assayed for protease as described in Methods.

Table 1. Effect of fatty acids on the secretion of extracellular enzymes by $B$. amyloliquefaciens in the presence of cerulenin

Suspensions of cells $(1 \mathrm{ml})$ were incubated in the presence of cerulenin $\left(100 \mu \mathrm{g} \mathrm{ml}^{-1}\right)$. The suspensions were supplemented with individual fatty acid species (prepared and dissolved in Tris buffer as described in Methods) at the indicated optimal concentrations. After $3 \mathrm{~h}$ the suspensions were centrifuged $(4000 \mathrm{~g}, 5 \mathrm{~min})$ and the supernatants were assayed for $\alpha$-amylase and protease activity as described in Methods. Fatty acids are denoted $\mathrm{C}_{x: y}$ where $x$ is the number of carbon atoms and $y$ is the number of double bonds; $n, i$ and $a$ denote straight-chain, iso and anteiso fatty acids, respectively.

\begin{tabular}{cccc} 
Supplement & $\begin{array}{c}\text { Concn } \\
\left(\mu \mathrm{g} \mathrm{ml}^{-1}\right)\end{array}$ & $\begin{array}{c}\text { Secretion of enzyme relative to } \\
\text { secretion in absence of cerulenin }(\%)\end{array}$ \\
\cline { 3 - 3 } None & - & $22 \cdot 8$ & Protease \\
$a-C_{15: 0}$ & 50 & $35 \cdot 4$ & $38 \cdot 2$ \\
$i-C_{16: 0}$ & 100 & $41 \cdot 2$ & $39 \cdot 0$ \\
$a-C_{17: 0}$ & 100 & $39 \cdot 0$ & $52 \cdot 0$ \\
$n-C_{16: 0}$ & 50 & $39 \cdot 7$ & $49 \cdot 1$ \\
& & & $43 \cdot 4$
\end{tabular}

\section{Effect of cerulenin on lipid to protein ratio}

In the presence of cerulenin, the membrane lipid to protein ratio [mg lipid (mg protein) ${ }^{-1}$ ] decreased from 1.03 to 0.70 over a $3 \mathrm{~h}$ incubation but remained unaltered in the absence of the drug. Adding the $B$. amyloliquefaciens fatty acid mixture at zero time did not significantly affect the ratios after $3 \mathrm{~h}$ in the presence or absence of cerulenin (ratios were 0.68 and 1.00 , respectively). 


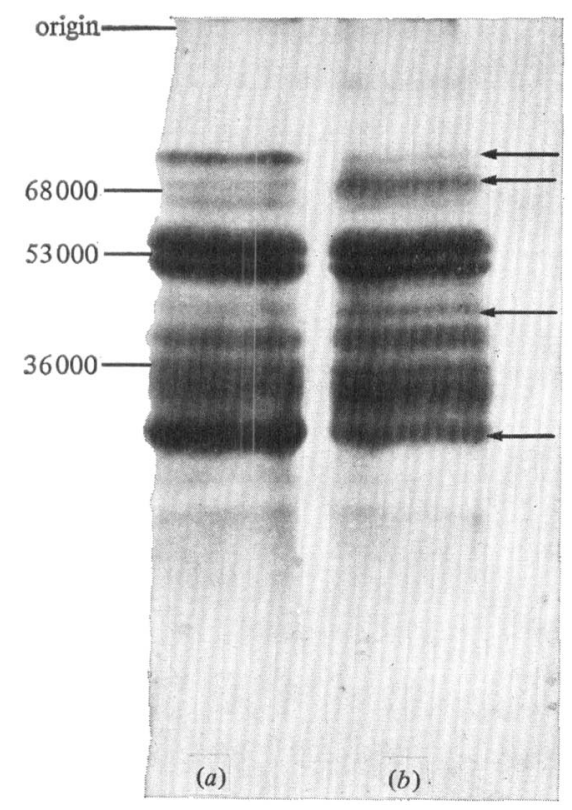

Fig. 9. Effect of cerulenin on membrane protein synthesis by B. amyloliquefaciens. Suspensions of cells were incubated for $3 \mathrm{~h}$ with $\left[{ }^{35} \mathrm{~S}\right]$ methionine $\left(1 \mu \mathrm{Ci} \mathrm{ml}{ }^{-1}\right)$ in the absence $(a)$ or presence $(b)$ of cerulenin $\left(100 \mu \mathrm{g} \mathrm{ml}^{-1}\right)$. Membranes were then prepared as described in Methods. Membrane proteins were precipitated with $10 \%(\mathrm{w} / \mathrm{v})$ trichloroacetic acid and analysed by SDS-polyacrylamide gel electrophoresis and fluorography as described in Methods. The mobilities of marker proteins of various molecular weights are indicated. The arrows indicate bands of altered intensity (see text).

Thus, there was no detectable increase in incorporation of fatty acids into membrane lipid in the presence of cerulenin, even though a restoration of enzyme secretion was achieved. This finding was confirmed using a ${ }^{14} \mathrm{C}$-labelled fatty acid mixture (prepared from B. amyloliquefaciens cells grown in the presence of $\left[1,2-{ }^{14} \mathrm{C}\right]$ acetate) and measuring the incorporation of label into lipid by cells in the presence or absence of cerulenin over $3 \mathrm{~h}$. The labelled fatty acid mixture was added at $100 \mu \mathrm{g} \mathrm{ml}^{-1}$ (sp.act. $10^{3}$ c.p.m. $\mu \mathrm{g}^{-1}$ ). In either the presence or absence of cerulenin the amount of labelled fatty acids incorporated into cell lipids was essentially the same. Only $3 \mu \mathrm{g}$ of exogenously added fatty acids were incorporated per $\mathrm{ml}$ of cell suspension and this represented only $2 \%$ (by wt) of the total amount of lipid present in these cells at zero time. Subsequent fractionation of total cell lipids by silicic acid column chromatography showed that in either the presence or absence of cerulenin about $64 \%$ of the incorporated radioactivity was associated with the phospholipid fraction, about $30 \%$ with the glycolipid fraction, while about $6 \%$ remained associated with neutral lipids.

\section{Effect of cerulenin on membrane proteins}

To investigate whether cerulenin affected the synthesis of membrane proteins, cells were incubated with $\left[{ }^{35} \mathrm{~S}\right]$ methionine for $3 \mathrm{~h}$ in the presence or absence of the drug. Membranes were then prepared and were shown, by electron microscopy of thin sections, to be totally devoid of ribosomes. The incorporation of $\left[{ }^{35} \mathrm{~S}\right]$ methionine into total membrane protein (measured as trichloroacetic acid precipitable material) was unaffected by cerulenin. SDS-polyacrylamide gel electrophoresis and fluorography showed that synthesis of the majority of individual membrane proteins was not affected by cerulenin (Fig. 9). An alteration in the amounts of four of the protein species was routinely observed (see arrows, Fig. 9) but this appeared to be unrelated to the inhibition of enzyme secretion since addition 
of the fatty acid mixture did not affect the amounts of these proteins synthesized in the presence of cerulenin (result not shown).

Cerulenin had virtually no effect on the activity of the electron transport chain in $B$. amyloliquefaciens. The rate of $\mathrm{O}_{2}$ uptake by intact cell suspensions after $3 \mathrm{~h}$ incubation in the absence of the drug was $116 \mathrm{nmol} \mathrm{O}_{2} \min ^{-1} \mathrm{ml}^{-1}$, compared with $112 \mathrm{nmol} \mathrm{O} \mathrm{min}^{-1} \mathrm{ml}^{-1}$ for suspensions incubated in the presence of the drug.

\section{DISCUSSION}

The antibiotic cerulenin, at a concentration which inhibited fatty acid synthesis by $75 \%$, also inhibited the secretion of total extracellular protein by $75 \%$ over $3 \mathrm{~h}$. To determine whether the two inhibitions were related, we examined the effect of cerulenin on the secretion of two extracellular proteins, $\alpha$-amylase and protease. Secretion of both enzymes was markedly inhibited by the drug although this inhibition was partially, but significantly, reversed by adding fatty acids. This suggests that protein secretion is dependent on the synthesis of fatty acids or derived lipids. The incomplete reversal observed may be due to poor utilization of the fatty acids. When ${ }^{14} \mathrm{C}$-labelled fatty acids were added only small amounts were incorporated; an amount equivalent to only $2 \%$ (by wt) of total cellular lipid was incorporated over $3 \mathrm{~h}$ in the presence or absence of cerulenin. Recently, it was shown that cerulenin had an effect unrelated to fatty acid synthesis. It inhibited the processing of structural membrane proteins of Rous sarcoma viruses but in contrast to the present study this effect was not reversed by the addition of fatty acids (Goldfine et al., 1978).

The inhibition of $\alpha$-amylase and protease secretion by cerulenin did not become maximal until approximately $60 \mathrm{~min}$ after adding the drug. This delayed effect could be explained by the presence of a reserve pool of fatty acids capable of supporting secretion for a limited period in the absence of de novo fatty acid synthesis. It is possible that a critical intracellular concentration of these fatty acids is required to support the maximal rate of protein secretion observed in control cells. There is no direct evidence for this suggestion, but it is compatible with the finding that although removal of cerulenin from cells by washing immediately restored fatty acid synthesis, $\alpha$-amylase secretion did not fully recover until $60 \mathrm{~min}$ after removal of the drug.

It is not known at what stage enzyme secretion is inhibited following cerulenin addition. Experiments (not reported) showed that there was no accumulation of intracellular material capable of reacting with antibodies to $\alpha$-amylase or protease in the presence of cerulenin, but such material may have been rapidly degraded intracellularly.

Treatment with cerulenin significantly altered the membrane lipid to protein ratio but had no effect on membrane processes such as amino acid transport and the activity of the electron transport chain. It seems highly unlikely that such a non-specific alteration in the membrane lipid content could be responsible for the observed inhibition of secretion without also affecting other membrane processes. Additionally, the membrane lipid to protein ratio in the presence of cerulenin was not affected under conditions in which inhibition of secretion was reversed. These results suggest that a major alteration in the lipid content of the membrane was not responsible for preventing secretion.

Perhaps the most significant aspect of this work is the clear difference in the effect of cerulenin on the production of extracellular proteins and integral membrane proteins, the latter being unaffected. From current theories of protein secretion (Blobel \& Dobberstein, 1975 ) and assembly of membrane proteins (Rothman \& Lenard, 1977) one would not have predicted any such difference. Rothman \& Lenard (1977) envisage that both classes of proteins are synthesized on membrane-bound ribosomes, the only difference being that membrane proteins do not completely traverse the bilayer but become fixed within it. The initial steps of entry into the membrane are envisaged as identical. Therefore, either the complete passage of secreted proteins requires an additional step, inhibited in the presence of cerulenin, or else the two processes are different in some other way not envisaged in current theories. 


\section{REFERENCES}

Altenbern, R. A. (1977). Extreme sensitivity of staphylococcal enterotoxin $\mathrm{B}$ and $\mathrm{C}$ production to inhibition by cerulenin. Antimicrobial Agents and Chemotherapy 11, 906-908.

Blobel, G. \& Dobberstein, B. (1975). Transfer of proteins across membranes. Journal of Cell Biology 67, 835-851.

BONNER, W. M. \& LASKeY, R. A. (1974). A film detection method for tritium-labelled proteins and nucleic acids in polyacrylamide gels. European Journal of Biochemistry 46, 83-88.

Both, G. W., McInnes, J. L., Hanlon, J. E., May, B. K. \& Elliott, W. H. (1972). Evidence for an accumulation of messenger RNA specific for extracellular protease and its relevance to the mechanism of enzyme secretion in bacteria. Journal of Molecular Biology 67, 199-217.

Caulfield, M., Chopra, I., Melling, J. \& Berkeley, R. C. W. (1976). The effect of cerulenin on the liberation of extracellular inducible levansucrase by Bacillus subtilis. Proceedings of the Society for General Microbiology 3, 91-92.

Fishman, Y., Rottem, S. \& Citri, N. (1978). Evidence linking penicillinase formation and secretion to lipid metabolism in Bacillus licheniformis. Journal of Bacteriology 134, 434 439.

Goldfine, H., Harley, J. B. \& Wyke, J. A. (1978). Effects of inhibitors of lipid synthesis on the replication of Rous sarcoma virus. A specific effect of cerulenin on the processing of major nonglycosylated viral structural proteins. Biochimica et biophysica acta 512, 229-240.

Konings, W. N., Bisschop, A., Veenhuts, M. \& Vermeulen, C. A. (1973). New procedure for the isolation of membrane vesicles of Bacillus subtilis and an electron microscopy study of their ultrastructure. Journal of Bacteriology 116, 1456-1465.
LAEMMLI, U. K. (1970). Cleavage of structural proteins during the assembly of the head of bacteriophage T4. Nature, London 227, 680-685.

LAzdunski, A., Murgier, M. \& LAzdunski, C. (1979). Phospholipid synthesis-dependent activity of aminopeptidase $\mathrm{N}$ in intact cells of Escherichia coli. Journal of Molecular Biology 128, 127-141.

O'Connor, R., Elliott, W. H. \& MAY, B. K. (1978). Modulation of an apparent mRNA pool for extracellular protease in Bacillus amyloliquefaciens. Journal of Bacteriology 136, 24-34.

OMURA, S. (1976). The antibiotic cerulenin, a novel tool for biochemistry as an inhibitor of fatty acid synthesis. Bacteriological Reviews 40, 681-697.

Paton, J. C., May, B. K. \& Elliott, W. H. (1978a). Membrane phospholipid asymmetry in Bacillus amyloliquefaciens. Journal of Bacteriology 135, 393-401.

Paton, J. C., McMurchie, E. J., May, B. K. \& Elliott, W. H. (1978b). Effect of growth temperature on membrane fatty acid composition and susceptibility to cold shock of Bacillus amyloliquefaciens. Journal of Bacteriology 135, 754-759.

Rinderknecht, J., Geokas, M. C., Silverman, P. \& KaverbaCK, B. J. (1968). A new ultrasensitive method for the determination of proteolytic activity. Clinica chimica acta 21, 197-203.

Rothman, J. E. \& Lenard, J. (1977). Membrane asymmetry. Science 195, 743-753.

SANDERS, R. L. \& MAY, B. K. (1975). Evidence for the extrusion of unfolded extracellular enzyme polypeptide chains through membranes of Bacillus amyloliquefaciens. Journal of Bacteriology 123, 806-814. 